\title{
Stomach
}

\section{Molecular Epidemiology of Gastric Cancer}

\author{
Teresa Starzyńska \\ Department of Gastroenterology, Pomeranian Medical Academy, Szczecin, Poland
}

\section{Key Words}

Gastric cancer $\cdot$ Molecular epidemiology $\cdot$ Markers of exposure $\cdot$ Markers of susceptibility

\begin{abstract}
Molecular epidemiology refers to the incorporation of molecular techniques in epidemiological studies. There are different biomarkers in cancer research used for molecular epidemiology including markers of exposure, markers of dose, susceptibility, treatment response, prognosis, altered structure/function and cancer type. Selected markers, especially those of exposure and susceptibility, are described in an example of gastric cancer. Clinical significance of molecular epidemiology is discussed. Copyright $\odot 2007$ S. Karger AG, Basel
\end{abstract}

'Traditional epidemiology' is very successful in identifying environmental and lifestyle factors that influence gastric cancer risk. However, gastric cancer has remained an important medical problem. It is still among the most common causes of cancer deaths in the world. Approximately 700,000 people die from this malignancy each year and around 1.1 million new cases are expected in the year 2010 [1].
(C) 2007 S. Karger AG, Basel

0257-2753/07/0253-0222\$23.50/0

Fax +4161306 1234

E-Mail karger@karger.ch

www.karger.com
Accessible online at: www.karger.com/ddi
Molecular epidemiology has been defined as 'a science that focuses on the contribution of potential genetic and environmental risk factors, identified at the molecular level, to the etiology, distribution and prevention of disease within families and across populations'. This new field has emerged from the integration of molecular techniques into conventional epidemiological research.

There are different biomarkers used for molecular epidemiology including markers of exposure (environmental and lifestyle factors potentially related to cancer risk), markers of dose (e.g. amount of cancer-causing factor) susceptibility, treatment response, prognosis, altered structure/function and cancer type [2].

\section{Gastric Cancer, Markers of Exposure}

\section{Helicobacter pylori}

A large body of literature indicates the important role of $H$. pylori as a factor contributing to the development of gastric carcinoma. The question is no longer whether gastric carcinoma is connected with infection, but which of the infected individuals are at particular risk.

Suganuma et al. [3] identified the TNF- $\alpha$-inducing protein (Tipalpha) gene family in $H$. pylori genome. They found that the Tipalpha proteins released from the bacteria act as carcinogenic factors through induction of 
TNF- $\alpha$ expression and NF- $\kappa \mathrm{B}$ activation. The authors further suggested that NF- $\kappa \mathrm{B}$ activation by Tipalpha may play a key role in stomach carcinogenesis. In order to underline the differences in the carcinogenic potential of bacteria, the authors proposed to divide $H$. pylori into four groups according to Tipalpha and cag PAI status.

The observations of Houghton et al. [4] suggest that Helicobacter infection may be the initiator of the carcinogenetic process by creating an environment favorable for recruitment of marrow stem cells (BMDCs).

\section{Epstein-Barr Virus}

Epstein-Barr virus (EBV)-associated gastric carcino$\mathrm{ma}(\mathrm{EBVaGC})$ has been reported from various regions of the world including Asia, Europe, North and South America [5-7]. EBV-encoded RNA was detected in about $1-20 \%$ of gastric tumors, in both diffuse and intestinal type. EBVaGC is usually located in proximal (cardia/body region) and remnant stomach, mostly in men. Association with a distinctive strain of EVB with gastric carcinoma has been proposed [6]. EBVaGC may develop through a different molecular mechanism comparing with gastric cancer without EBV infection being closely related with p16 abnormality [7]. The alterations of p53 and bcl 2 are a rare event in this subtype of cancer.

\section{JC Virus}

JC virus is a polyomavirus. Since this virus induces tumors in animal models, an association between JC virus and human malignancy has long been suspected. Recently, Shin et al. [8] were the first to describe that the oncogenic antigen of this virus is frequently present in gastric carcinoma.

\section{Markers of Susceptibility}

\section{Sporadic Gastric Cancer}

H. pylori, the most recognized etiological risk factor for sporadic gastric cancer, causes gastric damage by initiating chronic inflammation in mucosa. This process is mediated by an array of pro- and anti-inflammatory cytokines. Genetic polymorphisms of these cytokines, particularly interleukin (IL)-1, have emerged in recent years as an important determinant of gastric cancer susceptibility.

In 2000, El-Omar et al. [9] noted the association between three haplotypes of the IL-1 and an increased risk of both hypochlorhydria and gastric cancer. However, subsequent reports on this issue remained inconclusive, reporting both positive and negative associations [10]. Studies presenting a positive link emphasized that the effect appears more modest than was previously reported by El-Omar et al. Recent publications from Korea have demonstrated even the opposite association to be true. This discrepancy may reflect mostly the genetic difference between populations. The reason for this may also be due to potential confounding variables, such as $H$. $p y$ lori status, $H$. pylori-related pathogenetic factors and a family history of malignancy [10].

Also other cytokine gene polymorphisms (TNF- $\alpha$, IL10, IL-8) and their relevance to $H$. pylori-induced gastric cancer risk have been reported with inconsistent results [10]. Current studies from Asia on host factors and their impact on clinical outcomes in $H$. pylori infection suggest the poor metabolizer genotype status to be a risk factor for developing gastric cancer, especially for the diffuse type (OR 3.4) [11].

\section{Familial Gastric Cancer}

Familial gastric cancer represents about 5\% of stomach malignancy. The tumors may be of the diffuse and intestinal type. Inactivation of the gene coding the cellcell adhesion protein E-cadherin is found in about one third of cases with the diffuse subtype of familial gastric cancer.

According to recent data, stomach cancer is also a part of the spectrum of BRCA2 mutations and is the third most common malignancy in individuals carrying MLH1 and $\mathrm{MSH} 2$ germline mutations in mismatch repair gene $[5,12]$.

Molecular epidemiology of gastric cancer has provided a new insight for better understanding of the disease, especially the evidence that gastric cancer can be of BMDCs origin is a breakthrough discovery and might influence its management. However, despite the progress, the basis for the development of gastric cancer in a small subset of $H$. pylori-infected individuals remains to be defined. 


\section{References}

-1 Parkin DM, Bray F, Ferlay J, et al: Global cancer statistics, 2002. CA Cancer J Clin 2005; 55:74-108.

$\checkmark 2$ Chen Y-C, Hunter DJ: Molecular epidemiology of cancer. CA Cancer J Clin 2005;55:4554.

-3 Suganuma M, Kuzuhara T, Yamaguchi K, Fujiki H: Cancerogenic role of tumour necrosis factor- $\alpha$ inducing protein of Helicobacter pylori in human stomach. J Biochem Mol Biol 2006;39:1-8.

$>4$ Houghton J, Stoicov C, Roger A, Carbon J, Li H, Cai X, Fox J, Goldering J, Wang T: Gastric cancer originating from bone marrow-derived cells. Science 2004;306:1568-1571.

$\checkmark 5$ Stadtlander CH, Waterbor JW: Molecular epidemiology, pathogenesis and prevention of gastric cancer. Carcinogenesis 1999;20: 2195-2208.
6 Corvalan A, Ding S, Koriyama C, Carrascal E, Carrasquilla G, Backhouse C, Urza L, Argadona J, Palma M, Eizuru Y, Akiba S: Association of a distinctive statin of EpsteinBarr virus with gastric cancer. Int J Cancer 2006;118:1736-1742.

7 Ojima H, Saito K, Yamauchi H, Yamaki E, Idetu A, Hosouchi Y, Nishida Y, Tukada K, Kato H, Kuwano H: p16 protein abnormality in Epstein-Barr virus-associated gastric carcinoma. Anticancer Res 2006;26:933-937.

8 Shin SK, Li MS, Fuerst F, Hotchkiss E, Meyer R, Kim IT, Goel A, Boland CR: Oncogenic $\mathrm{T}$-antigen of JC virus is present frequently in human gastric cancer. Cancer 2006; 107:481488.

9 El-Omar EM, Carrington M, Chow WH, et al: Interleukin-1 polymorphisms associated with increased risk of gastric cancer. Nature 2000;404:398-402. Erratum in Nature 2001; 412:99.
10 Starzynska T, Malfertheiner P: Helicobacter and digestive malignancies. Helicobacter 2006; 11:32-35.

11 Sugimoto M, Furuta T, Shirai N, Nakamura A, Kajimura M, Sugimura H, Hishida A, Ishizaki T: Poor metabolizer genotype status of CYP2C19 is a risk factor for developing gastric cancer in Japanese patients with $\mathrm{He}$ licobacter pylori infection. Aliment Pharmacol Ther 2005;22:1033-1040.

12 Jakubowska A, Scott R, Menkiszak J, Gronwald J, Byrski T, Huzarski T, Górskii B, Cybulski C, Dębniak T, Kowalska E, Starzyńska T, Ławniczak M, Narod S, Lubiński J: A high frequency of BRCA2 gene mutations in Polish families with ovarian and stomach cancer. Eur J Hum Genet 2003;12:955-958. 